\title{
Influence of glyphosate underdoses on the suppression of Panicum maximum cultivars
}

\author{
Subdoses de glifosato na supressão de cultivares de Panicum maximum \\ Suzete Fernandes Lima ${ }^{*}$, Leandro Spíndola Pereira', Gustavo Dorneles Sousa',
Simonny Araújo Vasconcelo', Adriano Jakelaitis' ${ }^{1}$, José Franklin Athayde Oliveira'
}

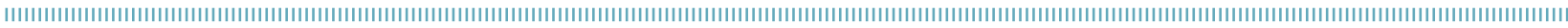

\begin{abstract}
The use of herbicide underdoses allows minimizing the competition of grasses on annual crops, enabling simultaneous cultivation. In this context, the objective of this study was to investigate glyphosate underdoses on the suppression of the initial growth of three Panicum maximum cultivars aiming at the integrated cultivation, in addition to the effects of forage species on the incidence and development of weeds. Three field experiments were conducted. The experimental design was a randomized block design with four replications and eight treatments consisting of increasing glyphosate doses $(0,54,108,270,378,540,756$, and 1,080 $\mathrm{g}$ a.e. $\left.\mathrm{ha}^{-1}\right)$. An atrazine dose of $1,200 \mathrm{~g}$ a.i. ha ${ }^{-1}$ was added to each treatment. Plant phytotoxicity assessments were performed at 7, 14, 21, and 28 days after application. At 80 and 125 days after sowing, the assessments of total dry matter production, leaf dry matter, stem dry matter, and leaf to stem ratio were carried out, in addition to density and dry matter production of weed community. Glyphosate underdoses below 215, 65, and $90 \mathrm{~g}$ a.e. ha $\mathrm{h}^{-1}$ have a potential to be investigated aiming at the management of $P$. maximum cv. Atlas, $P$. maximum cv. Mombasa, and $P$. maximum cv. Tanzania under intercropping. The three forage species are effective in suppressing weeds.
\end{abstract}

KEYWORDS: Atlas; Tanzania; Mombasa; crop-livestock integration system; weeds.
RESUMO: A utilização de subdoses de herbicidas permite amenizar a competição exercida pelas gramíneas sobre a cultura anual, viabilizando o cultivo simultâneo. Neste contexto, objetivou-se pesquisar subdoses de glifosato na supressão do crescimento inicial de três cultivares de Panicum maximum, almejando o cultivo integrado, além dos efeitos das forrageiras sobre a incidência e o desenvolvimento das plantas daninhas. Foram conduzidos três ensaios em campo. O delineamento experimental utilizado foi em blocos casualizados, com quatro repetiçóes e oito tratamentos, formados por doses crescentes do herbicida glifosato $(0 ; 54 ; 108 ; 270 ; 378$; 540; 756 e $1.080 \mathrm{~g}$ de e.a. ha $\left.{ }^{-1}\right)$. Em todos os tratamentos foram adicionados $1.200 \mathrm{~g}$ de i.a. ha ${ }^{-1}$ de atrazine. Foram realizadas avaliaçôes de fitointoxicação de plantas aos 7, 14, 21 e 28 dias após a aplicação. Aos 80 e 125 dias após a semeadura foram realizadas avaliaçóes de produçáo de matéria seca total, matéria seca de folha, matéria seca de colmos e relação folha: colmo, além da densidade e produção de matéria seca da comunidade de plantas daninhas. Subdoses de glifosato abaixo de 215, 65 e 90 g de e.a. ha ${ }^{-1}$ possuem potencial para serem pesquisadas visando ao manejo de Panicum maximum cv. Atlas, Panicum maximum cv. Mombaça e Panicum maximum cv. Tanzânia em consórcio. As três forrageiras são eficientes na supressão de plantas daninhas.

PALAVRAS-CHAVE: Atlas; Tanzânia; Mombaça; integração lavoura-pecuária; plantas daninhas. 


\section{INTRODUCTION}

Integrated production systems are considered innovative, aiming to maintain the sustainability of agricultural areas over the years. The adoption of intercropping systems makes crop rotation, increase of straw production for the no-tillage system, reduction of weed occurrence, and pasture supply during the off-season feasible (ALVES et al., 2013; CARMEIS FILHO et al., 2014; SILVA et al., 2015; MACHADO et al., 2017). These systems are complex and dynamic since there is more than one species occupying the same area, so the integration success depends on several factors.

Intercropping between annual crops and grasses stands out as a viable option (GARCIA et al., 2012). With the purpose of obtaining soil cover and straw, it benefits the crop in succession, resulting in a higher productivity (CHIODEROLI et al., 2010), in addition to influencing the weed dynamics (LIMA et al., 2014). Soybean planting during the season may be favored by intercropping due to the suppression of weed emergence exerted by the straw related to a fast growth of these cover species after harvesting the grain production crop (BORGHI et al., 2008).

Perennial species are more efficient when a higher biomass production during second season cultivations is sought (MACHADO et al., 2010). In this context, species of the genus Panicum are viable options to be inserted in these production systems due to their high nutritional value biomass related to a high percentage of leaves (EUCLIDES et al., 2010).

In southwestern Goiás State, the integrated corn-grass cultivation is an agronomic technique that enables the production of corn grains and increases straw production in the soybean-corn succession in order to guarantee the sustainability of the no-tillage system over the years (OLIVEIRA et al., 2016; QUEIROZ et al., 2016; ALMEIDA et al., 2017). However, intercropped forages may compete with corn and interfere with grain yield, making this cultivation system economically unfeasible (ALVES et al., 2013; FERRAZZA et al., 2016). This competition may lead to a reduction of up to $45 \%$ in corn productivity (ADEGAS et al., 2011).

Agronomic techniques can minimize the competition between crops simultaneously grown. Among them, the application of herbicide underdoses to suppress the initial forage growth is promising (CECCON et al., 2010; SILVA et al., 2014; GRIGOLLI et al., 2017). Thus, the success of an integrated cultivation between annual grain production crops and forages depends on the initial competitive advantage of the grain crop by environmental resources such as water, light, and nutrients.

With the emergence of genetically modified crops Roundup Ready (RR), the herbicide glyphosate became selective for these crops, allowing its application in the post-emergence period. This herbicide is used in the pre-sowing management for desiccation of spontaneous vegetation, especially in no-tillage areas. It is also used for weed management in perennial crop rows, as well as in post-emergence applications in genetically modified crops resistant to this molecule (PETTER et al., 2007; GOMES; CHRISTOFFOLETI, 2008; GALLI, 2009; CORREIA; DURIGAN, et al., 2010; ALBRECHT et al., 2014).

Considering that, glyphosate has the potential to be used in the management of forage species integrated with RR corn since its underdose applications promote important effects on growth and development of plants. However, information on the behavior of forage grasses submitted to glyphosate underdose application is still scarce. In this context, the objective of this study was to investigate glyphosate underdoses on the suppression of the initial growth of three Panicum maximum cultivars aiming at the integrated cultivation, in addition to the suppression in the incidence of weeds exerted by forages.

\section{MATERIAL AND METHODS}

The experiments were conducted in the field, in southwestern Goiás state, Brazil. Regional climate is Aw according to Köppen's classification, a mesothermal, savannah tropical climate, with rain in the summer and drought in the winter. Climatological data during the experimental period are shown in Figure 1. The soil of the experimental area is classified as a Hapludox (Soil Taxonomy; dystroferric Red Latosol, Brazilian Soil Classification). Before starting the experiments, soil samples were collected at a depth of $0-20 \mathrm{~cm}$ for chemical and physical analyses. Soil analysis results showed a pH of 6.2 (SMP), Ca of $4.64 \mathrm{cmol}_{\mathrm{c}}$ $\mathrm{dm}^{-3}, \mathrm{Mg}$ of $2.50 \mathrm{cmol}_{\mathrm{c}} \mathrm{dm}^{-3}, \mathrm{Al}^{3+}$ of $0.04 \mathrm{cmol}_{\mathrm{c}} \mathrm{dm}^{-3}, \mathrm{H}+\mathrm{Al}$ of $4.5 \mathrm{cmol}_{\mathrm{c}} \mathrm{dm}^{-3}$, CEC of $12.1 \mathrm{cmol}_{\mathrm{c}} \mathrm{dm}^{-3}, \mathrm{~K}_{\text {of }} 0.46 \mathrm{cmol}_{\mathrm{c}} \mathrm{dm}^{-3}$, $\mathrm{P}$ (Melich) of $13.1 \mathrm{mg} \mathrm{dm}^{-3}$, Cu of $2.3 \mathrm{mg} \mathrm{dm}^{-3}$, Fe of $13 \mathrm{mg}$ $\mathrm{dm}^{-3}, \mathrm{Mn}$ of $59.3 \mathrm{mg} \mathrm{dm}^{-3}$, OM of $3.62 \mathrm{mg} \mathrm{dm}^{-3}, \mathrm{Zn}$ of $4.5 \mathrm{mg}$ $\mathrm{dm}^{-3}$, base saturation of $62.8 \%$, aluminum saturation of $0.5 \%$, clay of $64.5 \%$, silt of $10.0 \%$, and sand of $25.5 \%$.

Three experiments were conducted with different cultivars of the genus Panicum (P. maximum cv. Atlas, P. maximum cv. Mombasa, and $P$. maximum cv. Tanzania). Before installing the experiments, spontaneous weed was chemically desiccated with glyphosate $\left(1,440 \mathrm{~g} \mathrm{ha}^{-1}\right)$. After 15 days, soil tillage was performed by means of a plowing and two harrowing.

The experimental design was a randomized block design with eight treatments and four replications composed of increasing glyphosate doses $(0,54,108,270,378,540,756$, and $1,080 \mathrm{~g}$ a.e. ha $\left.{ }^{-1}\right)$ of the commercial formulation Transorb ${ }^{\circledast} 480 \mathrm{~g} \mathrm{~L}^{-1}$. A dose of $1,200 \mathrm{~g}$ a.i. ha ${ }^{-1}$ of atrazine (Atrazine Nortox ${ }^{\circledR} 500 \mathrm{SC}$ ) was added to each treatment to control dicotyledonous weeds.

The experimental plots consisted of five rows of $3 \mathrm{~m}$ in length and a distance of $1 \mathrm{~m}$ between blocks. The useful area consisted of the two central rows, but without the borders of $0.5 \mathrm{~m}$ on both sides. Sowing was carried out on October 21, 2016 , using $5 \mathrm{~kg} \mathrm{ha}^{-1}$ of viable pure seeds sown in rows spaced $0.50 \mathrm{~m}$ at a depth of $0.05 \mathrm{~m}$. Sowing fertilization consisted of using $150 \mathrm{~kg} \mathrm{ha}^{-1}$ of the formulation 04-28-16. 
Thirty days after sowing (DAS), on November 11, 2016, treatments were applied using a $\mathrm{CO}_{2}$ pressurized sprayer equipped with a TT1 1002 four-nozzle boom spaced at $0.50 \mathrm{~m}$, positioned at $0.5 \mathrm{~m}$ height from the plant surface, with a spray solution volume of $150 \mathrm{~L} \mathrm{ha}^{-1}$, and a working pressure of 200 $\mathrm{KPa}$. The application was performed in the morning between 7:00 and 9:30 a.m, with a registered air temperature of $27^{\circ} \mathrm{C}$, relative air humidity of $76 \%$, wind speed of $1.0 \mathrm{~m} \mathrm{~s}^{-1}$, and moist soil at the surface. Adjacent plots were protected with a plastic canvas during the application in order to avoid drift.

The percentage of plant phytotoxicity was assessed at 7, 14, 21, and 28 days after treatment application (DAA), being established a percentage scale of 0 to $100 \%$, in which 0 represents no plant injury symptoms and 100 represents plant death (SBCPD, 1995).

Forage dry matter production was assessed at 80 and 125 DAS, on January 09 and February 23, 2017, respectively. For this, $1.5 \mathrm{~m}$ of $P$. maximum of the central row of each experimental unit was cut at $0.25 \mathrm{~m}$ height. Subsequently, forage fresh matter was measured and a sample of about $0.5 \mathrm{~kg}$ was taken for dry matter determination. This sample was separated into leaves, stems, and dead material, packed in paper bags, and dried in a forced air circulation chamber at $65^{\circ} \mathrm{C}$ for 72 hours for subsequent dry matter determination. In both assessment periods, the leaf to stem ratio (LSR) was calculated by dividing the dry matter values of leaves and stems.

After the first plant collection (80 DAS), a standardization cut was performed in the total experimental area by using a cleaver. The interval between the first and second forage cuttings was 45 days, period at which the cutting height of grasses was reached again.
In both periods ( 80 and $125 \mathrm{DAS}$ ), weed assessments were also performed. For this, two square frames of $0.25 \mathrm{~m}^{2}$ were randomly placed in each experimental unit, totaling $0.5 \mathrm{~m}^{2}$, being the weed species identified, separated, and counted. Subsequently, weeds were cut close to the soil and packed in paper bags to measure the dry matter, which was carried out in an analytical balance after drying in a forced air circulation chamber at $65^{\circ} \mathrm{C}$ for 72 hours.

The results were submitted to analysis of variance, with their means compared by the F-test $(\mathrm{p}<0.05)$ using the statistical program Systems for Statistical Analysis (SAEG) version 9.0 (RIBEIRO JÚNIOR, 2007). In the case of statistical significance, a regression analysis was performed with the program Sigmaplot (SISTAT SOFTWARE, version 12.0, San Jose). The data were fitted to a three-parameter sigmoidal nonlinear regression equation, as Equation 1, or to a twoparameter exponential nonlinear equation, as Equation 2.

$y=a l\left(1+\exp \left(-\frac{x-x_{0}}{b}\right)\right)$

$y=a \times \exp (-b \times x)$

Where:

$y$ is the response variable, $x$ is the herbicide dose, and $a, x_{0}$, and $b$ are the equation parameters, where $a$ in Equation 1 is the difference between the maximum and minimum points of the curve, $a$ in Equation 2 is the maximum value estimated for the response variable, $x_{0}$ is the dose that provides $50 \%$ response to the variable, and $b$ is the slope of the curve.

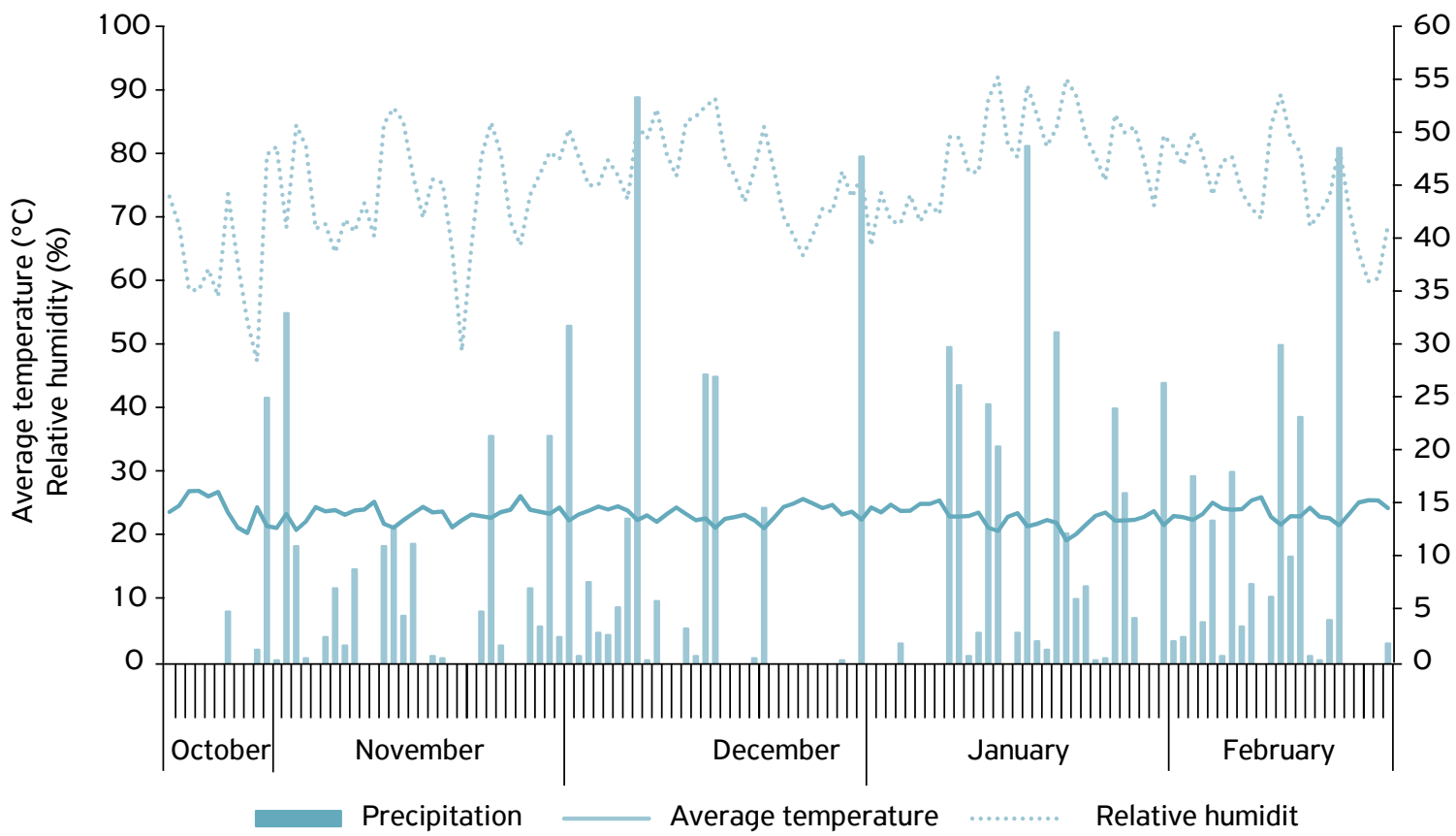

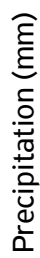

Figure 1. Average air temperature, relative air humidity, and total daily precipitation during the experimental period. 


\section{RESULTS AND DISCUSSION}

The parameters of the fitted sigmoidal model and the coefficients of determination for the percentage of phytotoxicity of forage species as a function of glyphosate underdoses are shown in Table 1 . The data presented a good fit, with an $\mathrm{R}^{2}$ between 92.12 and $99.96 \%$. The three $P$. maximum cultivars presented similar behavior, with a lower percentage of injuries at lower doses, while at higher doses plants were controlled, not presenting regrowth.

At the lowest doses of up to $200 \mathrm{~g}$ a.e. $\mathrm{ha}^{-1}$, the highest plant phytotoxicity occurred up to 14 DAA. After this period, injury symptoms began to decrease and plants resumed their vegetative growth, with new leaf emissions. These results demonstrate that there was only a stoppage of grass growth and soon they resume their growth.

The coefficient $a$ of the equations was above $91 \%$ for the three species in the four assessment periods. This indicates that from 7 to 28 DAA, low injury symptoms were observed in plants at lower underdoses, and high injury symptoms, even the control, were observed at higher underdoses, i.e. doses higher than $550 \mathrm{~g}$ a.e. ha ${ }^{-1}$.

In $P$. maximum cv. Mombasa and $P$. maximum cv. Atlas, glyphosate underdoses of 220 and $334 \mathrm{~g}$ a.e. ha ${ }^{-1}$, respectively,

Table 1. Parameters of the regression equations obtained by fitting the sigmoidal model and coefficient of determination $\left(R^{2}\right)$ applied to the means of phytotoxicity percentage of Panicum maximum cv. Atlas, $P$. maximum cv. Tanzania, and $P$. maximum cv. Mombasa at 7, 14, 21, and 28 days after application as a function of glyphosate doses $(0,54,108,270,378,540,756$, and $1,080 \mathrm{~g}$ a.e. $\left.\mathrm{ha}^{-1}\right)$ associated with atrazine $\left(1,200 \mathrm{~g}\right.$ a.i. ha- $\left.{ }^{-1}\right)$.

\begin{tabular}{|ccccc|}
\hline \multirow{5}{*}{ Variable } & \multicolumn{5}{c}{ Parameter $^{1}$} & R $^{2}$ \\
\cline { 2 - 5 } Panicum maximum cv. Atlas & $b$ & $x_{0}$ & \\
\hline 7 DAA & 98.7905 & 165.2166 & 334.3608 & $97.69^{*}$ \\
\hline 14 DAA & 95.9162 & 41.1133 & 109.6432 & $98.62^{*}$ \\
\hline 21 DAA & 98.6353 & 46.4424 & 161.4505 & $99.87^{*}$ \\
\hline 28 DAA & 99.4634 & 44.8494 & 220.8363 & $99.96^{*}$ \\
\hline Panicum maximum cv. Tanzania & & \\
\hline 7 DAA & 96.9497 & 119.1313 & 200.3558 & $96.49^{*}$ \\
\hline 14 DAA & 98.9736 & 47.7468 & 133.4072 & $99.64^{*}$ \\
\hline 21 DAA & 99.1265 & 38.2439 & 169.1719 & $99.75^{*}$ \\
\hline 28 DAA & 99.0903 & 22.3151 & 215.3763 & $99.93^{*}$ \\
\hline Panicum maximum cv. Mombasa & & \\
\hline 7 DAA & 91.7476 & 142.9868 & 220.4926 & $92.12^{*}$ \\
\hline 14 DAA & 97.1228 & 46.5283 & 107.4651 & $99.20^{*}$ \\
\hline 21 DAA & 98.9298 & 49.8437 & 145.9896 & $99.53^{*}$ \\
\hline 28 DAA & 98.9006 & 15.1247 & 109.1944 & $99.86^{*}$ \\
\hline
\end{tabular}

'Model: $y=a /\left(1+\exp \left(-\left(x-x_{0}\right) / b\right)\right) ;{ }^{2}$ DAA: days after application;

*significant by the F-test $(p \leq 0.05)$ provided $50 \%$ plant phytotoxicity at 7 DAA. However, at 28 DAA, underdoses of 109 and $220 \mathrm{~g}$ a.e. ha ${ }^{-1}$, respectively, provided $50 \%$ phytotoxicity, indicating that the initial injury symptoms at higher underdoses at 7 DAA are intensified up to 28 DAA. In P. maximum cv. Tanzania, on the other hand, this change did not occur between 7 and 28 DAA and the underdose of $215 \mathrm{~g}$ a.e. ha $\mathrm{a}^{-1}$ provided $50 \%$ phytotoxicity in plants.

At 7 DAA, the coefficient $b$ of the equation presented a higher value when compared to that observed at 28 DAA, which shows that at the beginning of the assessment, the slope of the curve was lower, i.e. plants presented injuries at the lower doses and had not yet been controlled at the highest doses. Over time, the slope of the curve tended to be more pronounced, indicating that plants recovered from phytotoxicity at the lowest doses and were controlled at the highest doses.

Glyphosate underdoses above 180, 315, and $410 \mathrm{~g}$ a.e. ha $^{-1}$ controlled $P$. maximum cv. Mombasa, $P$. maximum cv. Tanzania, and $P$. maximum cv. Atlas, respectively, leading them to death at 28 DAA. The cultivar Mombasa was more sensitive to glyphosate effect, presenting greater injury symptoms with the lowest underdose. Researching the desiccation efficiency of forage plants, FERREIRA et al. (2010) found a greater ease in the desiccation of $P$. maximum cv. Mombasa when compared to $P$. maximum cv. Tanzania with glyphosate herbicide. Thus, the cultivars of the genus Panicum have different susceptibility to the same herbicide.

Table 2 shows the data of total dry matter, leaf to stem ratio, leaf dry matter, stem dry matter, and dead material dry matter at 80 DAS, i.e. at the first grass cutting. The highest dry matter productions were obtained up to the glyphosate underdose of 215,67 , and $85 \mathrm{~g}$ a.e. ha ${ }^{-1}$ for $P$. maximum $\mathrm{cv}$. Atlas, P. maximum cv. Mombasa, and $P$. maximum cv. Tanzania, respectively. From these underdoses, a more marked reduction in forage production is observed. Therefore, lower underdoses, in which the reduction in biomass production was less than $20 \%$, should be investigated aiming at grass management.

In $P$. maximum cv. Atlas and $P$. maximum cv. Mombasa, the underdose that promoted $50 \%$ visual symptoms of plant phytotoxicity (220 and 109 g a.e. ha ${ }^{-1}$, respectively) was lower than the underdose that promoted $50 \%$ reduction in biomass production (288 and $160 \mathrm{~g}$ a.e. ha ${ }^{-1}$, respectively). This indicates that even without leaf chlorosis, the action of glyphosate herbicidal effect promoted a delay in forage development, leading to a lower biomass production.

The three grasses presented the same behavior for the leaf to stem ratio, leaf dry matter, and stem dry matter, with higher values for lower glyphosate underdoses and lower values for higher glyphosate underdoses. The highest values of leaf to stem ratio at the lowest underdoses are related to a higher biomass production and absence of flowering, which leads to a lower emission and elongation of stems.

The data of total dry matter, leaf to stem ratio, leaf dry matter, stem dry matter, and dead material dry matter in the 
second cut, performed at 125 DAS, with a 45-day interval from the first cut, are shown in Table 3. In the second cut, a lower biomass production was observed for the three forage species when compared to the first cut.

Panicum maximum cv. Tanzania showed the greatest potential for regrowth among the three forage species, with a $24 \%$ reduction in biomass production from the first to the second cut. On the other hand, $P$. maximum $\mathrm{cv}$. Mombasa and $P$. maximum cv. Atlas showed a reduction of 29 and $35 \%$, respectively. This result should be related to the intrinsic growth potential of each species, in addition to the effects of the glyphosate action, which provided different levels of stress in the forage species, influencing their vegetative development and consequent emission of new leaves.

Table 2. Parameters of the regression equations obtained by fitting the sigmoidal and exponential models and coefficient of determination $\left(\mathrm{R}^{2}\right)$ applied to the means of total dry matter ( $\mathrm{kg} \mathrm{ha}^{-1}$ ), leaf to stem ratio, leaf dry matter $\left(\mathrm{kg} \mathrm{ha}^{-1}\right)$, stem dry matter ( $\left.\mathrm{kg} \mathrm{ha}^{-1}\right)$, and dead material dry matter ( $\left.\mathrm{kg} \mathrm{ha}^{-1}\right)$ in the cultivation of Panicum maximum cv. Atlas, $P$. maximum cv. Tanzania, and $P$. maximum cv. Mombasa at 80 days after sowing (DAS) as a function of glyphosate doses $(0,54,108$, $270,378,540,756$, and 1,080 g a.e. ha ${ }^{-1}$ ) associated with atrazine $\left(1,200 \mathrm{~g}\right.$ a.i. $\left.\mathrm{ha}^{-1}\right)$.

\begin{tabular}{|c|c|c|c|c|}
\hline \multirow{2}{*}{ Variable } & \multicolumn{3}{|c|}{ Parameters of the sigmoidal fit ${ }^{1}$} & \multirow{2}{*}{$\mathbf{R}^{2}$} \\
\hline & $a$ & $b$ & $x_{0}$ & \\
\hline \multicolumn{5}{|c|}{ Panicum maximum cv. Atlas } \\
\hline TDM $^{2}$ & 5040.8844 & -52.7859 & 288.5447 & $97.91^{*}$ \\
\hline $\mathrm{LSR}^{3}$ & 2.7599 & -91.0798 & 525.7273 & $88.68 *$ \\
\hline $\mathrm{LDM}^{4}$ & 3577.8230 & -57.2052 & 285.6710 & 98.56* \\
\hline $\mathrm{SDM}^{5}$ & 1404.5405 & -48.9079 & 296.8892 & $91.72 *$ \\
\hline DMDM $^{6}$ & 76.6409 & -5.8960 & 251.7175 & $96.60^{*}$ \\
\hline \multicolumn{5}{|c|}{ Panicum maximum cv. Tanzania } \\
\hline TDM & 8156.8295 & -61.8432 & 147.4425 & $98.97^{*}$ \\
\hline LSR & 2.2350 & -197.1967 & 313.6012 & $93.74^{*}$ \\
\hline LDM & 5156.4556 & -61.1038 & 141.7043 & $98.72 *$ \\
\hline \multirow[t]{3}{*}{ SDM } & 2610.4552 & -53.6753 & 175.8434 & 98.70* \\
\hline & \multicolumn{3}{|c|}{ Parameters of the exponential fit ${ }^{7}$} & \multirow{2}{*}{$\mathbf{R}^{2}$} \\
\hline & $a$ & & $b$ & \\
\hline DMDM & 266,923 & & 0,0143 & $99,45^{*}$ \\
\hline \multicolumn{5}{|c|}{ Panicum maximum cv. Mombasa } \\
\hline TDM & 4446.03 & & 0.0043 & $87.31^{*}$ \\
\hline LSR & 4.7396 & & 0.0037 & $84.32 *$ \\
\hline LDM & 3408.59 & & 0.0044 & $86.36^{*}$ \\
\hline SDM & 840.226 & & 0.0039 & $90.34^{*}$ \\
\hline DMDM & 199.383 & & 0.0042 & $84.62 *$ \\
\hline
\end{tabular}

'Model: $y=a /\left(1+\exp \left(-\left(x-x_{0}\right) / b\right)\right) ;{ }^{2} \mathrm{TDM}$ : total dry matter; ${ }^{3} \mathrm{LSR}$ : leaf to stem ratio; ${ }^{4}$ LDM: leaf dry matter; ${ }^{5} \mathrm{SDM}$ : stem dry matter; ${ }^{6} \mathrm{DMDM}$ : dead material dry matter; ${ }^{7}$ model: $y=a \times \exp (-b \times x)$; ${ }^{*}$ significant by the F-test $(p \leq 0.05)$
The herbicidal effect of glyphosate is less pronounced at 125 DAS when compared to 80 DAS. At the first assessment period, underdoses of 288,147 , and $160 \mathrm{~g}$ a.e. $\mathrm{ha}^{-1}$ promoted a $50 \%$ reduction in biomass production for $P$. maximum $\mathrm{cv}$. Atlas, P. maximum cv. Tanzania, and P. maximum cv. Mombasa, respectively. For the same percentage of reduction at 125 DAS, underdoses of 488,376 , and $289 \mathrm{~g}$ a.e. $\mathrm{ha}^{-1}$ were required for P. maximum cv. Atlas, P. maximum cv. Tanzania, and P. maximum cv. Mombasa, respectively, which shows their potential for recovering from the herbicidal effect.

The data of density and dry matter of weeds at 80 and 125 DAS are shown in Table 4. The main weeds in the experimental area were Commelina benghalensis, Cenchrus echinatus, Digitaria horizontalis, Eleusine indica, Cyperus rotundus, Alternanthera tenella, Nicandra physaloides, Ipomoea grandifolia, Ricinus communis, and Vigna angularis. A low density and dry matter production of weeds were observed in the three grasses at 80 DAS.

Table 3. Parameters of the regression equations obtained by fitting the sigmoidal model and coefficient of determination $\left(R^{2}\right)$ applied to the means of total dry matter $\left(\mathrm{kg} \mathrm{ha}^{-1}\right)$, leaf to stem ratio, leaf dry matter $\left(\mathrm{kg} \mathrm{ha}^{-1}\right)$, stem dry matter ( $\mathrm{kg}$ ha $\left.{ }^{1}\right)$, and dead material dry matter $\left(\mathrm{kg} \mathrm{ha}^{-1}\right)$ in the cultivation of Panicum maximum cv. Atlas, $P$. maximum cv. Tanzania, and $P$. maximum cv. Mombasa at 125 days after sowing as a function of glyphosate doses $(0,54,108,270,378,540,756$, and $1,080 \mathrm{~g}$ a.e. $\left.\mathrm{ha}^{-1}\right)$ associated with atrazine $(1,200 \mathrm{~g}$ a.i. ha-1 $)$.

\begin{tabular}{|c|c|c|c|c|}
\hline \multirow{2}{*}{ Variable } & \multicolumn{3}{|c|}{ Parameter $^{1}$} & \multirow{2}{*}{$\mathbf{R}^{2}$} \\
\hline & $a$ & $\boldsymbol{b}$ & $x_{0}$ & \\
\hline \multicolumn{5}{|c|}{ Panicum maximum cv. Atlas } \\
\hline TDM $^{2}$ & 4352.5174 & -1.0783 & 488.4844 & $95.48 *$ \\
\hline $\mathrm{LSR}^{3}$ & 13.1919 & -113.8163 & 124.3607 & $69.09 *$ \\
\hline $\mathrm{LDM}^{4}$ & 3288.0511 & -3.5524 & 491.0252 & $95.59 *$ \\
\hline $\mathrm{SDM}^{5}$ & 1039.5508 & -4.2009 & 487.7343 & $67.58^{*}$ \\
\hline DMDM $^{6}$ & & $\bar{Y}=0.00$ & & $n s^{7}$ \\
\hline \multicolumn{5}{|c|}{ Panicum maximum cv. Tanzania } \\
\hline TDM & 5691.3971 & -1.6006 & 376.7705 & 99.71 * \\
\hline LSR & 6.7183 & -169.9263 & 58.7023 & $96.36^{*}$ \\
\hline LDM & 3583.6559 & -47.6065 & 367.7009 & $94.56^{*}$ \\
\hline SDM & 2129.2086 & -4.2450 & 373.9636 & $81.32 *$ \\
\hline DMDM & & $\bar{Y}=10.37$ & & ns \\
\hline
\end{tabular}

Panicum maximum cv. Mombasa

$\begin{array}{lcccc}\text { TDM } & 5895.5532 & -6.8020 & 589.1171 & 96.85^{*} \\ \text { LSR } & 4.3834 & -16.5481 & 279.5821 & 95.49^{*} \\ \text { LDM } & 2292.6390 & -7.6583 & 284.1551 & 97.68^{*} \\ \text { SDM } & 600.5643 & -0.2450 & 341.0704 & 89.18^{*} \\ \text { DMDM } & & \bar{Y}=19.63 & & n s\end{array}$

'Model: $y=a /\left(1+\exp \left(-\left(x-x_{0}\right) / b\right)\right)$; ${ }^{2}$ TDM: total dry matter; ${ }^{3}$ LSR: leaf to stem ratio; ${ }^{4} \mathrm{LDM}$ : leaf dry matter; ${ }^{5} \mathrm{SDM}$ : stem dry matter; ${ }^{6} \mathrm{DMDM}$ : dead material dry matter; ${ }^{7}$ not significant; * ${ }^{*}$ significant by the F-test $(p \leq 0.05)$ 
The absence of a statistical difference at 80 DAS is related to the application of the herbicide atrazine, which controls the germination of weed seeds in the soil seed bank, in addition to exerting influence on the development of some weeds when applied at the beginning of their development. When using atrazine in the corn-brachiaria intercropping, CECCON et al. (2010) found only stunted weeds in the harvest period, which were later suppressed.

At 125 DAS, we noticed a higher density and biomass production of weeds at higher glyphosate underdoses due to a reduction in the development or even death of grasses, leaving the soil uncovered, which favors germination and development of weed seeds already present in the soil. In this period, there is no longer the influence of the herbicide atrazine on the weed community, whose half-life time, a parameter used to estimate its persistence in the soil, is 55 days (RODRIGUES; ALMEIDA, 2005). However, the residual effect is highly influenced by edaphoclimatic conditions (ULBRICH et al., 2005). The accumulation of a precipitation of $244 \mathrm{~mm}$ in December 2016 and $288 \mathrm{~mm}$ in January 2017 (Fig. 1) may have contributed to reducing the residual effect of the atrazine herbicide.

On the contrary, at lower glyphosate underdoses, the grasses expressed their suppression potential on the weed community. The development of grasses, with a consequent soil cover, reduces density and development of weeds, being an alternative for straw production for sowing the crop in succession (CECCON et al., 2010; LIMA et al., 2014; LIMA et al., 2016). Grass growth, with consequent soil cover, inhibited weed growth, evidencing the importance of using cultural practices for the integrated management of weeds.

\section{CONCLUSIONS}

Glyphosate underdoses below 215, 67, and 85 g a.e. ha ${ }^{-1}$ have potential to be investigated aiming at the management of $P$. maximum cv. Atlas, P. maximum cv. Mombasa, and $P$. maximum cv. Tanzania under intercropping.

Forages species had a strongly inhibited growth, with phytotoxicity symptoms above $50 \%$ for glyphosate underdoses above 220,109 , and $215 \mathrm{~g}$ a.e. ha ${ }^{-1}$ for $P$. maximum cv. Atlas, $P$. maximum cv. Mombasa, and $P$. maximum cv. Tanzania, respectively.

The grasses $P$. maximum cv. Atlas, P. maximum cv. Mombasa, and $P$. maximum cv. Tanzania are effective in suppressing weeds.

\section{ACKNOWLEDGMENTS}

To the Federal Instituto Goiano for financial support.

Table 4. Parameters of the regression equations obtained by fitting the sigmoidal model and coefficient of determination $\left(R^{2}\right)$ applied to the means of weed density (plants $\mathrm{m}^{-2}$ ) and weed dry matter $\left(\mathrm{g} \mathrm{m}^{-2}\right)$ in the cultivation of Panicum maximum cv. Atlas, $P$. maximum cv. Tanzania, and $P$. maximum cv. Mombasa at 80 and 125 days after sowing as a function of glyphosate doses $(0,54$, $108,270,378,540,756$, and 1,080 g a.e. ha-1) associated with atrazine ( $\left.1,200 \mathrm{~g} \mathrm{a.i.}^{-1} \mathrm{ha}^{-1}\right)$.

\begin{tabular}{|c|c|c|c|c|c|}
\hline & \multirow{2}{*}{ Variable } & \multicolumn{3}{|c|}{ Parameter $^{1}$} & \multirow{2}{*}{$\mathbf{R}^{2}$} \\
\hline & & $a$ & $b$ & $x_{0}$ & \\
\hline \multicolumn{6}{|c|}{ Panicum maximum cv. Atlas } \\
\hline \multirow{2}{*}{$80 \mathrm{DAS}^{2}$} & $D^{3}$ & \multicolumn{3}{|c|}{$\bar{Y}=3.88$} & $n s^{5}$ \\
\hline & $\mathrm{DM}^{4}$ & \multicolumn{3}{|c|}{$\bar{Y}=1.55$} & ns \\
\hline \multirow{2}{*}{125 DAS } & D & 28.1231 & 147.8042 & 374.9644 & $92.12^{*}$ \\
\hline & DM & 1022.5395 & 222.8827 & 884.9224 & 99.41 * \\
\hline \multicolumn{6}{|c|}{ Panicum maximum cv. Tanzania } \\
\hline \multirow{2}{*}{80 DAS } & $\mathrm{D}$ & \multicolumn{3}{|c|}{$\bar{Y}=8.56$} & ns \\
\hline & DM & \multicolumn{3}{|c|}{$\bar{Y}=1.39$} & ns \\
\hline \multirow{2}{*}{125 DAS } & D & \multicolumn{3}{|c|}{$\bar{Y}=10$} & ns \\
\hline & DM & 512.7761 & 105.1919 & 407.2303 & $99.55^{*}$ \\
\hline \multicolumn{6}{|c|}{ Panicum maximum cv. Mombasa } \\
\hline \multirow{2}{*}{80 DAS } & D & \multicolumn{3}{|c|}{$\bar{Y}=8.69$} & ns \\
\hline & DM & \multicolumn{3}{|c|}{$\bar{Y}=1.69$} & ns \\
\hline \multirow{2}{*}{125 DAS } & $\mathrm{D}$ & 16.6000 & 4.7498 & 110.7031 & $75.54 *$ \\
\hline & DM & 348.3691 & 24.9604 & 299.8774 & $95.69 *$ \\
\hline
\end{tabular}

'Model: $y=a /\left(1+\exp \left(-\left(x-x_{0}\right) / b\right)\right) ;{ }^{2} \mathrm{DAS}$ days after sowing; ${ }^{3} \mathrm{D}$ : weed density; ${ }^{4} \mathrm{DM}$ : weed dry matter; ${ }^{5}$ not significant; ${ }^{*}$ significant by the $\mathrm{F}$-test ( $\leq 0.05$ ) 

REFERENCES

ADEGAS, F. S.; VOLL, E.; GAZZIERO, D. L. P. Manejo de plantas daninhas em milho safrinha em cultivo solteiro ou consorciado à braquiária ruziziensis. Pesquisa Agropecuária Brasileira, v.46, n.10, p.1226-1233, 2011.

ALBRECHT, A. J. P.; ALBRECHT, L. P.; BARROSO, A. A. M.; VICTORIA FILHO, R. O milho RR2 e o glyphosate: uma revisão. Revista Brasileira de Herbicidas, v.13, n.1, p.58-67, 2014. 10.7824/ rbh.v13i1.279

ALMEIDA, R. E. M. de; GOMES, C. M.; LAGO, B. C.; OLIVEIRA, S. M. de; PIEROZAN JÚNIOR, C.; FAVARIN, J. L. Corn yield, forage production and quality affected by methods of intercropping corn and Panicum maximum. Pesquisa Agropecuária Brasileira, v.52, n.3, p.170-176, 2017. http://dx.doi.org/10.1590/ s0100-204x2017000300004

ALVES, V. B.; PADILHA, N. de S.; GARCIA, R. A.; CECCON, G. Milho safrinha consorciado com Urochloa ruziziensis e produtividade da soja em sucessão. Revista Brasileira de Milho e Sorgo, v.12, n.3, p.280-292, 2013

BORGHI, E.; COSTA, N. V.; CRUSCIOL, C. A. C.; MATEUS, G. P. Influência da distribuição espacial do milho e da Brachiaria brizantha consorciados sobre a população de plantas daninhas em sistema plantio direto na palha. Planta Daninha, v.26, n.3, p.559-568, 2008. http://dx.doi.org/10.1590/S0100-83582008000300011

CARMEIS FILHO, A. C. de A.; CUNHA, T. P. L. da; MINGOTTE, F. L. C.; AMARAL, C. B. do; LEMOS, L. B.; FORNASIERI FILHO, D. Adubação nitrogenada no feijoeiro após palhada de milho e braquiária no plantio direto. Revista Caatinga, Mossoró, v.27, n.2, p.66-75, 2014

CECCON, G.; MATOSO, A. O.; NETO NETO, A. L.; PALOMBO, L. Uso de herbicidas no consórcio de milho safrinha com Brachiaria ruziziensis. Planta Daninha, v.28, n.2, p.359-364, 2010. http:// dx.doi.org/10.1590/SO100-83582010000200015

CHIODEROLI, C. A.; MELLO, L. M. M.; GRIGOLLI, P. J.; SILVA, J. O. R.; CESARIN, A. L. Consorciação de braquiárias com milho outonal em plantio direto sob pivô central. Engenharia Agrícola, Jaboticabal, v.30, n.6, p.1101-1109, 2010. http://dx.doi. org/10.1590/SO100-69162010000600011

CORREIA, N. M.; DURIGAN, J. C. Controle de plantas daninhas na cultura de soja resistente ao glyphosate. Bragantia, v.69, n.2, p.319-327, 2010. http://dx.doi.org/10.1590/ S0006-87052010000200009

EUCLIDES, V. P. B.; VALLE, C. B. do; MACEDO, M. C. M.; ALMEIDA, R. G. de; MONTAGNER, D. B.; BARBOSA, R. A. Brazilian scientific progress in pasture research during the first decade of XXI century. Revista Brasileira de Zootecnia, Viçosa, v.39, (Suppl. spe), p.151-168, 2010. http://dx.doi.org/10.1590/ S1516-35982010001300018

FERRAZZA, R. de A.; LOPES, M. A.; ALBUQUERQUE, C. J. B. Avaliação bioeconômica do consórcio de sorgo com diferentes espécies forrageiras para sistema de integração lavoura-pecuária em Nova Porteirinha, MG. Boletim de Indústria Animal, v.73, n.2, p.94-102, 2016.

FERREIRA, A. C. de B.; LAMAS, F. M.; CARVALHO, M. da C. S.; SALTON, J. C.; SUASSUNA, N. D. Produção de biomassa por cultivos de cobertura do solo e produtividade do algodoeiro em plantio direto. Pesquisa Agropecuária Brasileira, v. 45, n. 6, p. 546-553, 2010.

GALLI, A. J. B. A molécula glyphosate e a agricultura brasileira. In: VELLINI, E. D.; MESCHEDE, D.; CARBONARI, C. A.; TRINDADE, M. L. B. Glyphosate. Fepaf: Botucatu, 2009. p. 17-19.

GARCIA, C. M. de P.; ANDREOTTI, M.; TARSITANO, M. A. A.; TEIXEIRA FILHO, M. C. M.; LIMA, A. E. da S.; BUZETTI, S. Análise econômica da produtividade de grãos de milho consorciado com forrageiras dos gêneros Brachiaria e Panicum em sistema plantio direto. Revista Ceres, v.59, n.2, p.157-163, 2012. http://dx.doi. org/10.1590/SOO34-737X2012000200002

GOMES JÚNIOR, F. G.; CHRISTOFFOLETI, P. J. Biologia e manejo de plantas daninhas em áreas de plantio direto. Planta Daninha, v.26, n.4, p.789-798, 2008. http://dx.doi.org/10.1590/ so $100-83582008000400010$

GRIGOLLI, J. F. J.; GITTI, D. de C.; LOURENÇÃO, A. L. F. Controle de plantas de soja e supressão do capim em milho consorciado com Brachiaria ruziziensis. Arquivos do Instituto Biológico, v.84, e0592015, 2017. http://dx.doi. org/10.1590/1808-1657000592015

INMET. Instituto Nacional de Meteorologia. 2016. Available from: <http://www.inmet.gov.br>. Accessed on: March, 2017.

LIMA, S. F.; TIMOSSI, P. C.; ALMEIDA, D. P.; SILVA, U. R. Palhada de braquiária ruziziensis na supressão de plantas daninhas na cultura da soja. Revista Agrarian, v.7, n.26, p.541-551, 2014.

. Métodos de semeadura e aplicação de 2,4-D na formação de braquiária ruziziensis para plantio direto. Cultura Agronômica, Ilha Solteira, v.25, n.2, p.175-186, 2016.

MACHADO, L. A. Z.; ASSIS, P. G. G. de. Produção de palha e forragem por espécies anuais e perenes em sucessão à soja. Pesquisa Agropecuária Brasileira, v.45, n.4, p.415-422, 2010.

MACHADO, L. A. Z.; CECATO, U.; COMUNELLO, E.; CONCENÇO, G.; CECCON, G. Estabelecimento de forrageiras perenes em consórcio com soja, para sistemas integrados de produção agropecuária. Pesquisa Agropecuária Brasileira, v.52, n.7, p.521-529, 2017.

OLIVEIRA, B. P. de; FERREIRA, J. O.; SILVA, C. F. da; SILVA, A. C.; CEDRO, D. A. B. de; ALBINO, J. L. D. Diferentes forrageiras em consórcio com milho destinado a silagem. Interdisciplinar: Revista Eletrônica da UNIVAR, n. 15, v. 1, p. 170-173, 2016.

PETTER, F. A.; PROCÓPIO, S. O.; CARGNELUTTI FILHO, A.; BARROSO, A. L. L.; PACHECO, L. P. Manejo de herbicidas na cultura da soja Roundup Ready ${ }^{\circledR}$. Planta Daninha, v. 25, n. 3, p. 557-566, 2007. http://dx.doi.org/10.1590/SO100-83582007000300015 
QUEIROZ, R. F. de; CHIODEROLI, C. A.; FURLANI, C. E. A.; HOLANDA, H. V. de; ZERBATO, C. Maize intercropped with Urochloa ruziziensis under no-tillage system. Pesquisa Agropecuária Tropical, v.46, n.3, p.238-244, 2016. http:// dx.doi.org/10.1590/1983-40632016v4640464

RIBEIRO JÚNIOR, J. I. Análises estatísticas no SAEG. Viçosa: UFV, 2007. $301 \mathrm{p}$.

RODRIGUES, B. N.; ALMEIDA, F. S. Guia de herbicidas. 5. ed. Londrina: Edição dos Autores, 2005. 592p.

SILVA, P. I. B.; FONTES, D. R.; MORAES, H. M. F.; GONÇALVES, V. A.; SILVA, D. V.; FERREIRA, L. R.; FELIPE, R. S. Crescimento e rendimento do milho e da braquiária em sistema consorciado com diferentes manejos de plantas daninhas. Planta Daninha, v.32, n.2, p.301-309, 2014. http://dx.doi.org/10.1590/ S0100-83582014000200007

SILVA; A. G. da; HORVATH NETO, A.; TEIXEIRA, I. R.; COSTA, K. A. P. da; BRACCINI, A. L. Seleção de cultivares de sorgo e braquiária em consórcio para produção de grãos e palhada. Semina: Ciências Agrárias, v. 36, n. 5, p. 2951-2964, 2015.

SOCIEDADE BRASILEIRA DA CIÊNCIA DAS PLANTAS DANINHAS (SBCPD). Procedimentos para instalação, avaliação e análise de experimentos com herbicidas. Londrina: SBCPD, 1995. 42p.

ULBRICH, A. V.; SOUZA, J. R. P.; SHANER, D. Persistence and carryover effect of imazapic and imazapyr in Brazilian cropping systems. Weed Technology, v. 19, n. 4, p. 986-991, 2005. https://doi.org/10.1614/WT-04-208R2.1 